\title{
Whole genome molecular characterization of Infectious Pancreatic Necrosis Viruses isolated in Turkey
}

\author{
Yüksel DURMAZ1,a,®, Harun ALBAYRAK ${ }^{2, b}$ \\ ${ }^{1}$ Veterinary Control Institute, Fish Diseases Laboratory, Samsun; ${ }^{2}$ Ondokuz May1s University, Faculty of Veterinary Medicine, \\ Department of Virology, Samsun, Turkey. \\ ${ }^{\mathrm{a} O R C I D: 0000-0003-1347-5278 ;}{ }^{\mathrm{b} O R C I D: 0000-0002-4468-2790}$
}

$\triangle$ Corresponding author: samsunfishlab@hotmail.com

Received date: 08.03.2019- Accepted date: 20.09.2019

\begin{abstract}
Infectious pancreatic necrosis virus (IPNV; Birnaviridae, Aquabirnavirus) causes infectious pancreatic necrosis (IPN) in fish. IPN disease was first found in 2002 in Turkey. In this study, 10 IPNV isolates were isolated between 2005 and 2013 and propagated in RTG-2 cell cultures. RNAs obtained from cell lysates were used as template and VP1, VP2, VP3, VP4 and VP5 genes of the virus were amplified in full length. Sequence analyses of the genes were made. The obtained sequences were compared with international reference strains from GenBank and phylogenetic analyses and genogrouping of the viruses were conducted. Turkish isolates were found to show a genetic similarity of between $93.5 \%$ and $99.8 \%$ in terms of molecules. When segment A sequences were compared with each other, a similarity between $97.8 \%$ and $99.8 \%$ was found; when they were compared with international reference strains, they were found to have the highest similarity (99.3\%) with France AJ622822 isolate and the lowest (65.7\%) similarity with Canada NC001915 isolate. When segment B sequences of the isolates were compared with each other, a similarity between $93.5 \%$ and 99.5\% was found; when they were compared with international reference strains, they were found to have the highest similarity (98.9\%) with Canada M58757 isolate and the lowest (52.7\%) similarity with Finland KY548519 strain. As a result of phylogenetic analyses conducted, Turkish isolates were found to be closely related with France, Spain and Iran strains in serotype A2 and genogroup 5 they were placed in.
\end{abstract}

Keywords: IPNV, molecular characterization, RT-PCR, Turkey, whole genome.

\section{Türkiye’den izole edilen İnfeksiyöz Pankreatik Nekrozis Viruslarının tüm genom moleküler karakterizasyonu}

Özet: İnfeksiyöz pankreatik nekrozis virusu (IPNV; Birnaviridae, Aquabirnavirus) balıklarda infeksiyöz pankreatik nekrozis (IPN) hastalığını oluşturmaktadır. IPN hastalığı Türkiye'de ilk kez 2002 yılında tespit edilmiştir. Bu çalışmada 2005 ve 2013 yılları arasında izolasyonu yapılan 10 adet IPNV izolatı RTG-2 hücre kültürlerinde üretildi. Hücre lizatlarından elde edilen RNA'lar kalıp olarak kullanılarak virusun VP1, VP2, VP3, VP4 ve VP5 genleri tam uzunlukta amplifiye edildi. Genlerin dizi analizleri gerçekleştirildi. Elde edilen sekanslar GenBank'tan sağlanan uluslararası referans suşlar ile karşılaştırılarak virusların fillogenetik analizleri ve genogruplandırılmaları yapıldı. Türkiye izolatlarının moleküler yönden \% 93,5 ile \% 99,8 oranında genetik benzerlik gösterdiği saptandı. Segment A sekansları kendi aralarında \% 97,8 ile \% 99,8 oranında, uluslararası referans suşlarla karşıllaştırıldığında ise en yüksek oranda (\% 99,3) Fransa AJ622822 izolatı ile en düşük oranda (\% 65,7) Kanada NC001915 izolatı ile benzerlik bulundu. Segment B sekansları kendi aralarında \% 93,5 ile \% 99,5 oranında, uluslararası referans suşlarla karşılaştırıldıklarında ise en yüksek oranda (\% 98,9) Kanada M58757 izolatı ile en düşük oranda (\% 52,7) Finlandiya KY548519 suşu ile benzerlik bulundu. Yapılan filogenetik analizler sonucunda Türkiye izolatlarının serotip A2 ve genogrup 5 içinde yerleştikleri Fransa, İspanya ve İran suşları ile yakın ilişsili oldukları belirlendi.

Anahtar sözcükler: IPNV, moleküler karakterizasyon, RT-PCR, tüm genom, Türkiye.

\section{Introduction}

Infectious pancreatic necrosis virus (IPNV) is a small non-enveloped virus of Aquabirnavirus genus from Birnaviridae family; it has genome 2 segmented (A and B) RNA structure, it has double stranded and linear with a diameter of 60 nanometer and it is surrounded with an icosahedral capsid $(8,25)$. IPNV causes high levels of mortality in fry and young farm fish $(1,27)$. The fish which survive the infection remain as life-long asymptomatic carrier (19). In our country, this disease was first diagnosed in 2002 and it was found that the disease was more common in many trout farms (4).

The larger segment, A, is 3,097 nucleotides long and encodes a $107-\mathrm{kDa}$ precursor protein $(9,13,28)$ in a single 
large open reading frame (ORF), which is cotranslationally cleaved by the viral nonstructural (NS) protease, VP4, generating VP2 and VP3 structural proteins (5, 8-10). Segment A also encodes a 15-kDa arginine-rich protein from a small ORF partly preceding and overlapping the polyprotein $\operatorname{ORF}(6,11)$. VP2 also includes virulence markers $(3,17)$. In virulent IPNV strains, there are Threonine and Alanine (Thr217/Ala221) at 217 and 221 positions of VP2, respectively, while there are Proline and Ala (Pro217/Ala221) amino acid residues at this position in moderate or low virulence strains. Strains with 221 Threonine position are almost avirulent $(21,24)$. VP3 is an internal protein. The smaller genomic segment, B, is 2784 nucleotides (nt) long and encodes VP1, the virion-associated RNA-dependent RNA polymerase $(10,15)$.

Aquabirnaviruses are grouped in 4 (A-B-C-D) serogroups $(16,27)$. Most of the aquabirnaviruses are in Serogroup A and this group is divided into 9 serotypes (A1-A9). These serotypes are represented by West Buxton (A1), Sp (A2), Ab (A3), He (A4), Te (A5), Can1 (A6), Can2 (A7), Can 3 (A8) and Jasper (A9) reference strains (19). Serogroup B consists of a single serotype B1. Serotype A1 includes America isolates, while serotype A6-A9 includes Canada isolates and serotypes A2-A5 and B1 include Europe and Asia isolates (3, 16, 17). Aquabirnaviruses have been classified according to the phylogenetic analysis results of VP2 gene and 6 genogroups have been reported in 9 serotypes of Serogroup A $(1,3)$. Genogroup 1 includes serotypes A1 and A9, genogroup 2 includes serotype A3, genogroup 3 includes serotypes A5 and A6, genogroup 4 includes serotypes A7 and A8, genogroup 5 includes serotype A2 and genogroup 6 includes serotype A4 (20, 23, 25). In addition to these 6 genogroups, it has been proposed to classify all aquabirnaviruses as genogroup $7(3,13,19)$.

The purpose of this study is to conduct the whole genome molecular characterization of native IPNV isolates, to genogroup them and to compare the viruses with known European and American genotypes.

\section{Material and Methods}

Cells and virus isolates: 15 number ethical board approval was taken for the study from local ethics committee of Veterinary Control Institute. Rainbow trout gonad cells were obtained from Ondokuz Mayis University, Faculty of Veterinary Medicine, Department of Virology. In this study a total of 10 virus isolates were selected from 66 isolates that were used number 2130156 Project of TUBITAK conducted by Ondokuz Mayıs University in 2014 and 2017 years. These viruses are isolated by Bornova Veterinary Control Institute Department of Virology (Muğla07 KY606185, Hatay07 KY606187, Aydin07 KY606192, Antalya07 KY606213, Uşak05 KY606229, Ankara10 KY606221), Samsun
Veterinary Control Institute Virology Laboratory (Almus KM972672), Trabzon Central Fisheries Research Institute Fish Health Diseases Laboratory experts (Hah-2 KM972673, Hah-3 KM972674, Hah-4 KM972675) during outbreaks and routine field screening. Three of them from the province of Trabzon, and one from each of the provinces of Muğla, Hatay, Aydın, Antalya, Uşak, Ankara and Tokat (9 rainbow trout and 1 turbot origin), isolated between 2005 and 2013, were used.

Cell culture and propagation of viruses: The local IPNV isolates were propagated in RTG-2 cells at $15^{\circ} \mathrm{C}$. The cells were grown at $23^{\circ} \mathrm{C}$ in $\mathrm{L}-15$ medium (Gibco, 1929865) supplemented with $10 \%$ fetal bovine serum (FBS) (Sigma, 094M3335) and 2 mML-glutamine (Gibco, 1788084). For preparation of local IPNV virus stocks, confluent RTG-2 cells grown at $25^{\circ} \mathrm{C}$ were infected at a multiplicity of infection (MOI) of 0.001 in MEM (Gibco, 12492013 ) with $5 \% \mathrm{FBS}$. After $1 \mathrm{~h}$ of adsorption at $15^{\circ} \mathrm{C}$, the inoculum was removed, and the cells were incubated at $15^{\circ} \mathrm{C}$ until extensive cytopathic effect (CPE) was observed. The supernatant was collected 7 days after postinfection, clarified and stored at $-80^{\circ} \mathrm{C}$ for further processing. Second passage of viruses were used further studies.

PCR analysis of genes: RNA extraction was made with commercially obtained kit (Thermo GeneJET, K0732) and RT-PCR studies were conducted with OneStep RT-PCR kit (Qiagen, 163012798), according to the directions of the manufacturer firm. VP2, VP5 (2), VP3, VP4 and VP1 (6) gene areas of the viruses were amplified in vitro by using specific primers and using genomic RNAs stocked at $-20{ }^{\circ} \mathrm{C}$ as template (Table 1) (18). Mix preparation and PCR conditions of all genes were the same; however, since VP1 gene was long, it was amplified in two pieces as VP1a and VP1b and for VP1 gene, annealing heat was changed as $50^{\circ} \mathrm{C}$. Since VP5 gene and VP2 gene overlapped except the first 7 nucleotide, the amplification of these genes was made on single fragment. A reaction of 11 PCR was prepared for the amplification of each gene. For this purpose, reaction tubes which included a $50 \mu \mathrm{l}$ mixture of $10 \mu \mathrm{l} 5 \mathrm{X}$ Buffer (12.5 mM $\left.\mathrm{MgCl}_{2}\right), 1 \mu \mathrm{l}(0.2 \mathrm{mM}) \mathrm{dNTP}$ mix, $2 \mu \mathrm{l}$ each primer (10 pmol), $1 \mu$ l enzyme (RT, DNA pol), $2.5 \mu \mathrm{l}$ (5 $\mathrm{mM}) \mathrm{DTT}, 5 \mu \mathrm{l}$ RNA and $26.5 \mu \mathrm{l}$ distilled water were put in thermal cycler. The steps of amplification on thermal cycler were set up as follows: The reaction mixture was incubated at $50^{\circ} \mathrm{C}$ for 30 minutes. The reverse transcriptase enzyme was then inactivated by holding at $95^{\circ} \mathrm{C}$ for 15 minutes was followed consecutively by 30 seconds at $55^{\circ} \mathrm{C}, 70$ seconds at $72^{\circ} \mathrm{C}$, and 30 seconds at $94^{\circ} \mathrm{C}$, which were repeated 35 times. Amplification was terminated by final extension at $72^{\circ} \mathrm{C}$ for 10 minutes. The resulting DNA products (amplicon) were analyzed on agarose gel $(1.5 \%)$ after electrophoresis at $80 \mathrm{~V}$ for 30 minutes. The DNA bands were observed under ultraviolet light (Figure 1). 
Table 1. DNA sequences and target regions of the primers.

\begin{tabular}{|c|c|c|c|}
\hline Primers & Aligment & Localisation & References \\
\hline FVP1A & 5'- ATG TCG GAC ATC TTC AAY TCA CC -3' & $101-123$ & \multirow{2}{*}{ Dadar et al. (6) } \\
\hline RVP1A & 5'- GAG CCG TCC TCG TTT GTC CA -3' & $1379-1398$ & \\
\hline FVP1B & 5'- CAC ATG CAG GCA ATG ATG TAC TAC -3' & $1340-1364$ & \multirow{2}{*}{ Dadar et al. (6) } \\
\hline RVP1B & 5'- CCT AGT TTC TTC TCT GCT TCT C -3' & $2614-2636$ & \\
\hline FVP3 & 5'- GCA TCC GGG ATG GAC GAG GA -3' & $2207-2226$ & \multirow{2}{*}{ Dadar et al. (6) } \\
\hline RVP3 & 5'- TTA CAC CTC AGC GTT GTC TCC -3' & 2956-2977 & \\
\hline FVP4 & 5'- GGA CCA GAG TCT TCA ACG AAA TCA CG -3' & $1275-1300$ & \multirow{2}{*}{ Dadar et al. (6) } \\
\hline RVP4 & 5'- TAG ATC TCG GCG TCC TGG ACT TC -3' & $2377-2400$ & \\
\hline SPAF 1 & 5'- GGA AAG AGA GTT TCA ACT TTA GTC G -3' & $1-24$ & \multirow{2}{*}{ Albayrak (2) } \\
\hline SPAR 1 & 5'- GAC TCC AGC CTG TTC TTG AGG -3' & $1675-1686$ & \\
\hline
\end{tabular}
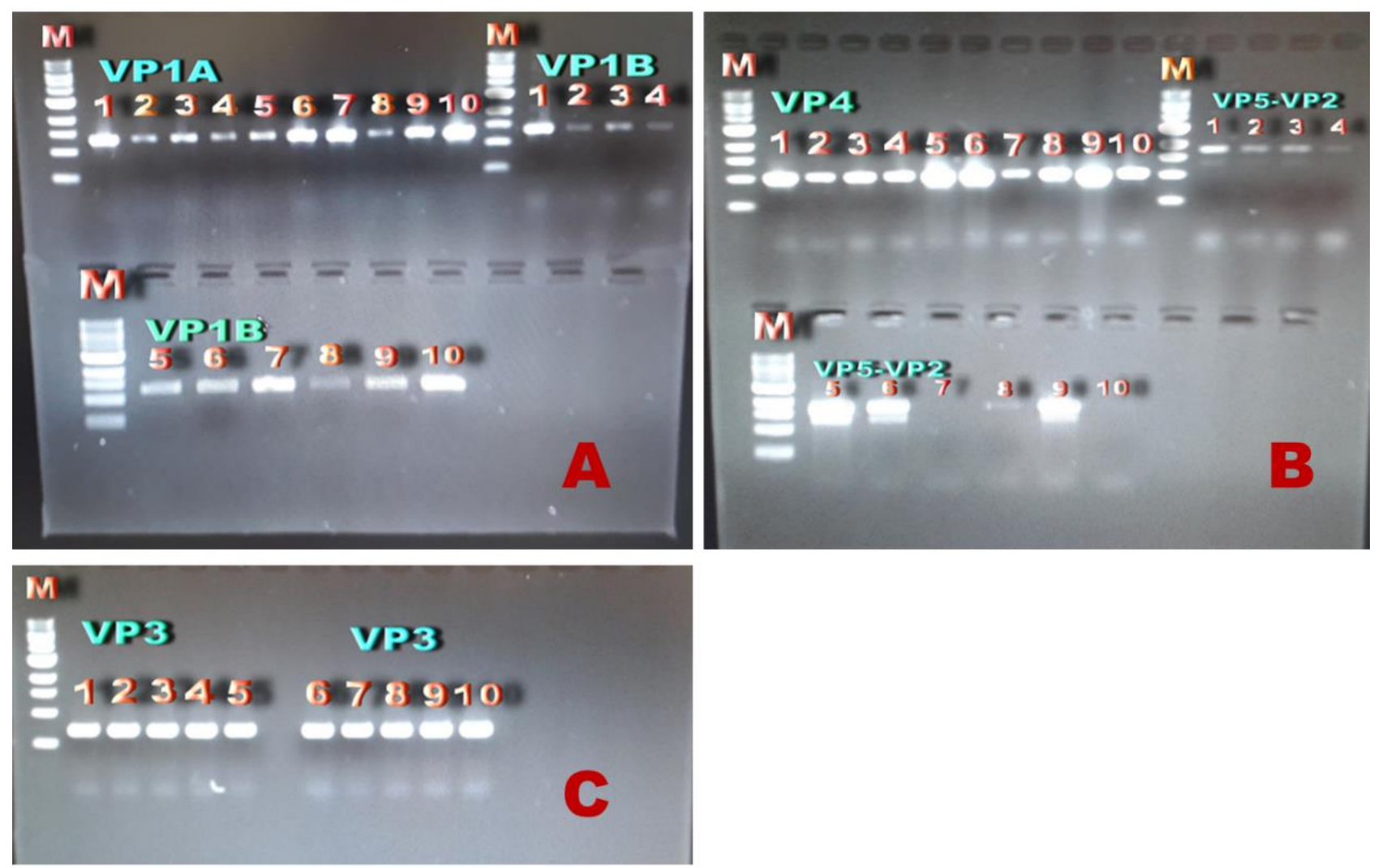

Figure 1. Specific bands of VP1, VP2, VP3, VP4 and VP5 genes. A. 1297 bp VP1A and 1296 bp VP1B specific PCR, B. 1125 bp VP4 and 1662 bp VP5-VP2 specific PCR, C. 770 bp VP3 specific PCR. M: 500 bp molecular weight standard; 1: Almus isolate; 2: Uşak05 isolate; 3: Hah-2 isolate; 4: Hah-3 isolate; 5: Hah-4 isolate; 6: Antalya07 isolate; 7: Muğla07 isolate; 8: Ankara10 isolate; 9 : Hatay07 isolate; 10: Aydın07 isolate.

Sequencing of PCR products: A total of 50 PCR product 2 direction (as forward and reverse) 100 sequencing with 5 different primer pairs was performed by a commercial firm by using Sanger method. Sequencing and assessment was performed with BioEdit sequence alignment editor program, while integration was performed with Contig express program. Segment A and Segment B sequences were compared within their own groups and also compared with reference virus sequences. Phylogenetic trees were created and genogroup comparisons were made.

\section{Results}

After the first passage of the viruses, CPE formation was observed in 6 isolates, while it was seen in all of the 10 isolates after the second passage. In PCR analyses, VP1 specific bands were observed at 1296 and 1297 bp, VP3 specific bands were observed at $770 \mathrm{bp}$, VP4 specific bands were observed at $1125 \mathrm{bp}$ and VP5 and VP2 specific bands were observed at $1662 \mathrm{bp}$. No band was observed at VP5-VP2 gene area for Muğla07 and Aydın07 isolates (Figure 1). 
Table 2. Informations of IPNV strains which were made phylogenetic analysis.

\begin{tabular}{cccccc}
\hline Genogroup & Strain & GenBank accession number & Geographical origin & Reference region & Nucleotide sequence \\
\hline I & Ja & NC001915 & Canada & Segment A & $1-3097$ \\
I & WB & AF078668 & Canada & Segment A & $1-3097$ \\
II & Ab & AF342729 & Denmark & Segment A & $1-2904$ \\
III & C1 & AF342732 & Canada & Segment A & $1-2904$ \\
III & TE & AF342731 & England & Segment A & $1-2904$ \\
IV & 1146 & AJ489222 & Spain & Segment A & $1-2919$ \\
IV & C2 & AF342733 & Canada & Segment A & $1-2904$ \\
IV & C3 & AF342734 & Canada & Segment A & $1-2904$ \\
V & Hatay07 & MH614926 & Turkey & Segment A & $1-3097$ \\
V & Antalya07 & MH614927 & Turkey & Segment A & $1-3097$ \\
V & Uşak05 & MH614928 & Turkey & Segment A & $1-3097$ \\
V & Almus & MH614929 & Turkey & Segment A & $1-3097$ \\
V & Hah-2 & MH614930 & Turkey & Segment A & $1-3097$ \\
V & Hah-3 & MH614931 & Turkey & Segment A & $1-3097$ \\
V & Hah-4 & MH614932 & Turkey & Segment A & $1-3097$ \\
V & Heh-5 & KF991533 & Turkey & Segment A & $1-1572$ \\
V & Almus-1 & KF914646 & Turkey & Segment A & $1-1779$ \\
V & SP & KF279643 & Iranian & Segment A & $1-3096$ \\
V & 31-75 & AJ622822 & France & Segment A & $1-1510$ \\
V & N-137 & HQ457181 & Norway & Segment A & $1-1510$ \\
V & I-2 & HQ457195 & Ireland & Segment A & $1-2904$ \\
VI & He & AF342730 & Germany & &
\end{tabular}

Segment B sequencing was performed in all of the 10 studied isolates; however, all sequences of segment A was not performed in Muğla07, Aydın07 and Ankara10 isolates. Whole Segment A was sequenced in 7 isolates. It was found that VP5 termination codon of Almus, Antalya07, Hah-2, Hah-3, Hah-4 and Uşak05 isolates was terminated at 496 nucleotide base, while Hatay07 isolate was terminated as 511 nucleotide base. Amino acid residues of VP2 gene at 217/221/247 positions related with virulence were identified as Proline/Threonine/ Glutamic acid (Glu) (PTE) in Almus and Hah-4 isolates, while it was identified as PTA in Antalya07, Hah-2, Hah3, Hatay07 and Uşak05 isolates. It was found that small ORF on segment A started a protected sequence at nucleotide 112 with ATGCAA and encoded 2 different VP5 proteins - one protein cut with early termination codon at 496 nucleotide and a $15 \mathrm{kDa}$ whole protein at 511 base. It was found that large ORF terminated at nucleotide 3037 with TAA termination codon it started at nucleotide 119, 7 nucleotides after small ORF, and encoded VP2, VP3 and VP4 proteins. Amino acid residues of Turkish isolates were found as Pro217, Thr221, Ala247 or Glu247, respectively. All the sequence data analyzed were stored at GenBank Database and 13 reference IPNV representing all genogroups obtained from GenBank was compared with Segment A sequence and phylogenetic assessments were made (Table 2).

While the amino acid similarity of segment A was between $98 \%$ and $99.8 \%$ in Turkish isolates (Table 3), amino acid similarity of segment B was between $93.5 \%$ and $99.1 \%$ (Table 4). Segment B amino acids have higher rates of differences. The closest similarity of native isolates in segment A nucleotides was found with France isolate AJ622822 between $97.3 \%$ and $98.6 \%$, with Iran isolate KF279643 between $97.8 \%$ and $98.5 \%$, with Spain isolate AJ489222 between $98.3 \%$ and $98.8 \%$. Nucleotides of these isolates and native isolates were found to have a similarity of more than $97.3 \%$. The highest difference between nucleotides was found as $34.3 \%$ between native isolates and Canada isolate NC001915 and as 23.3\% between native isolates and Germany isolate AF342730 (Table 3). With phylogenetic studies, IPNV isolated from Turkey were classified within genogroup 5 (Figure 2) and this genogroup includes Europe and Asia isolates (Iran Sp, France 31-75, Norway N-137 and Ireland I-2). 10 Segment B sequences analyzed were stored in GenBank Database and their data were compared with 25 IPNV segment B sequence data and their phylogenetic analysis was made (Figure 3) While the segment B amino acid similarity of native isolates among themselves was found to be between $93.5 \%$ and $99.1 \%$, their nucleotide similarity was found to be between $97.4 \%$ and $99.5 \%$ (Table 4). While more than $97.5 \%$ nucleotide similarity was found between native isolates and Canada M58757 isolate, the lowest similarity was found with Finland KY548519 strain at a rate of $64.2 \%$. Between native isolates and segment B amino acids of reference strains, more than $93.3 \%$ similarity was found between Canada M58757, France AJ622823, Norway AY379743, AY823633, AY379739, America AY354522, AY354523, AY354524, AY379741 isolates. 
Figure 2. Dendrogram obtained with the neighbor-joining method using 1000 bootstrap in Turkish isolates and reference strains according to Segment A.
Figure 3. Phylogram obtained with the neighbor-joining method using 1000 bootstrap in Turkish isolates and reference strains according to Segment B.
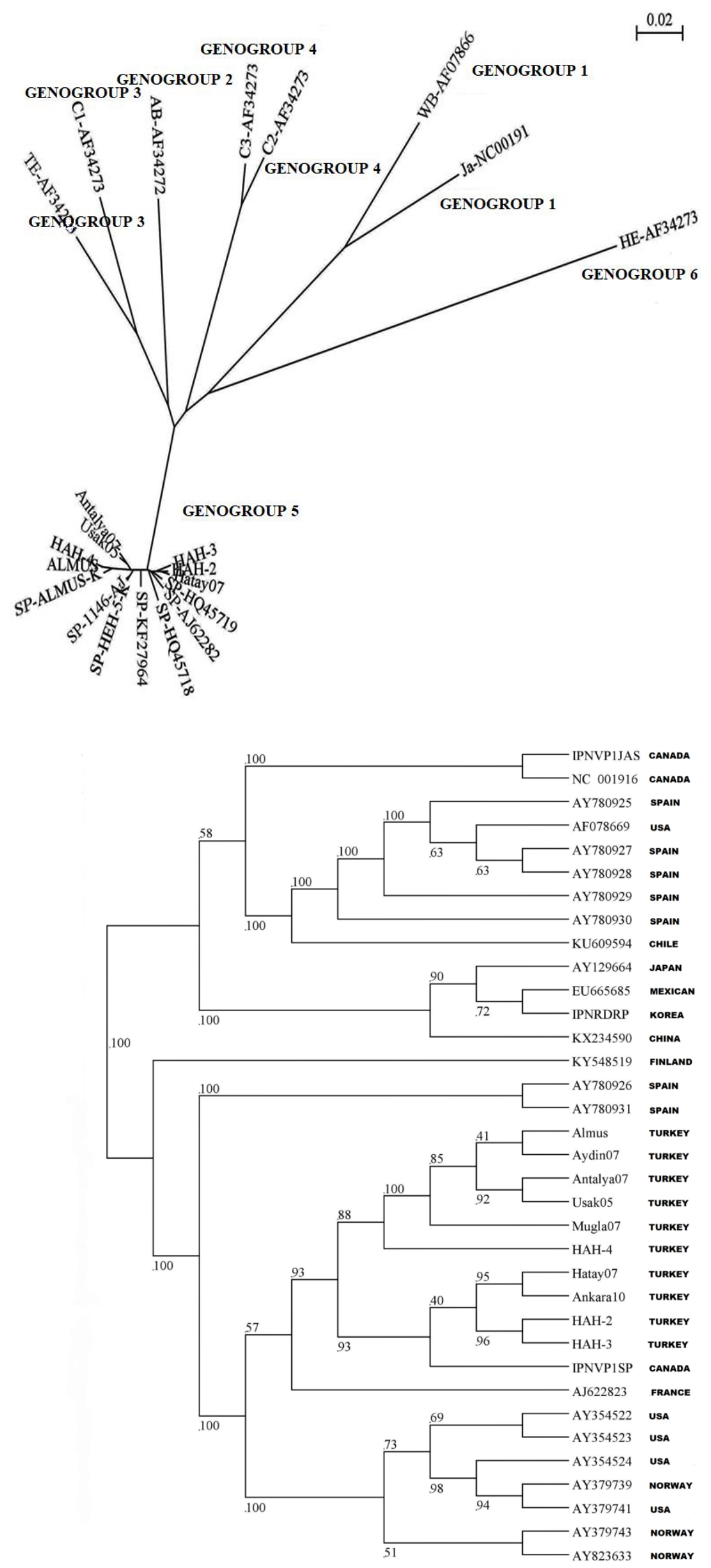


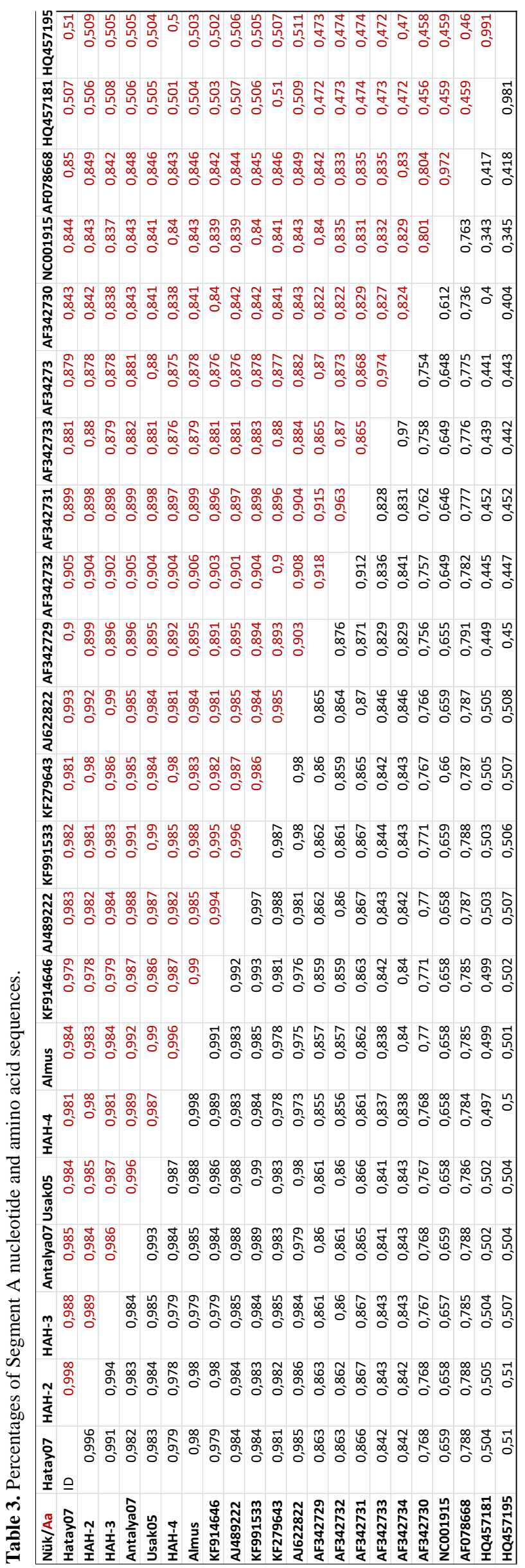




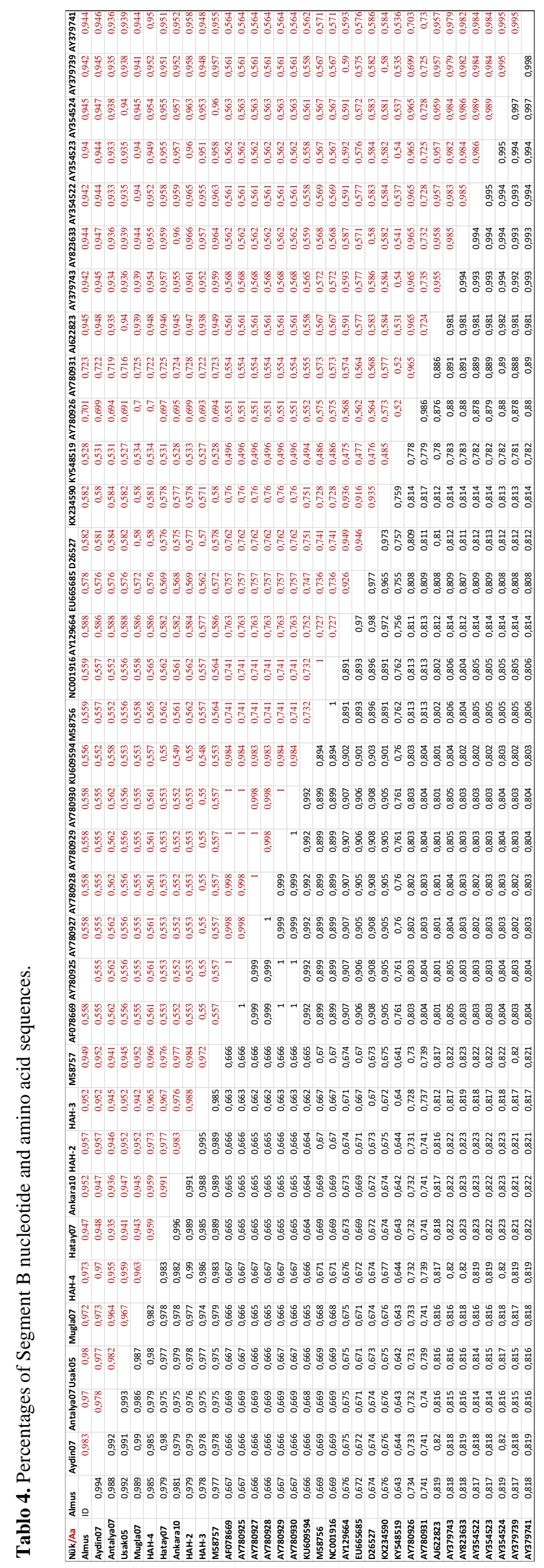




\section{Discussion and Conclusion}

Our study is the first to perform whole genome sequence and molecular characterization of rainbow trout and turbot originated IPNV isolates in Turkey. Molecular analyses showed very small genetic differences among isolates. These small genetic differences show that fish and their eggs are transferred among farms from geographically remote areas and that the virus is spread in a wide area.

Since mutation was reported after 8th passage on CHSE-214 cell lines in previously conducted studies with IPNV (25), passages were made on RTG-2 cell lines and low passage numbered strains were studied. Our phylogenetic analysis results show that Turkish isolates are within genogroup 5 and serotype A2 and they are closely related with France, Spain and Iran strains. Almost all of the Thr221 containing isolates in genogroup 5 are avirulent and they are responsible for the occurrence of carrier or persistent infections in salmons $(20,22,25)$. RNA viruses are known to adapt quickly to environmental conditions. In non-enveloped viruses, adaptation mutations generally occur in external capsid proteins which function as virus cell binding and receptor defining protein (25). In our study, Almus and Hah-4 isolates were found to undergo a point mutation from Ala to Glu at VP2 gene 247 position, unlike the GenBank accession number KM972672 and KM972675 parent virus. The beginning of VP5 protein start codon may change (7). Start codon of VP5 has been shown to be placed at 68 or 112 position (12). In addition, Weber et al. (26) and Shivappa et al. (23) showed that in Sp strains, second start methionine codon is responsible for starting VP5. According to Segment A sequences, VP5 start codon was found to be placed at 112 nucleotide and be responsible for starting VP5 translation of the second methionine in Turkish strains.

In small ORF encoding VP5 at IPNV genome, a great number of hotspot points are observed. VP5 mutations include amino acid residue 29, 36, 45 and 106. As a result of the changes in these areas, 3 different types of VP5 are occurred. The first stop codon in this ORF normally appears at nucleotide 511, resulting in a polypeptide of 133 amino acids. Some isolates had a premature stop codon at nucleotide 496, encoding a polypeptide shorter by five amino acids. Others could encode a truncated NS protein of 105 amino acids, having a stop codon at nucleotide 427 (14). In all of the 7 isolates sequenced in our study, this gene encodes VP5 protein. Isolates were found to encode both 133 aa full length VP5 protein and 128 aa cut VP5 protein.

As a result of phylogenetic analyses, amino acids of segment $\mathrm{A}$ in Almus, Antalya07, Uşak05 and Hah-4 isolates were found to show more than $99 \%$ similarity. In Hah-2, Hah-3, Hatay07, Uşak05 and Antalya07 isolates, all nucleotides of virus genome were found to be more than 99\% similar. This result brought to mind that the source of these viruses which were isolated in different years and cities were the same and they were circulated among the cities. Hah-2 strain was isolated from turbots and Hah-3 strain was isolated from a salmon in Trabzon in 2010, while Hatay07 strain was isolated from a salmon in Hatay in 2007. The result that more than 99\% molecular similarity was found between salmon isolate Hah-2 and turbot isolates Hatay07 and Hah-3 brought to mind that this virus was transferred between fish species.

Segment A sequences of Turkish isolates were found to show a similarity between $97.8 \%$ and $99.8 \%$. When compared with international reference strains, while the lowest similarity (65.7\%) was found between Canada strain NC001915 and Hah-3 isolate, the highest similarity (99.3\%) was found between France isolate J622822 and Hatay07. Segment B sequences of Turkish isolates were found to show a similarity between $93.5 \%$ and $99.5 \%$. When compared with international reference strains, while the lowest similarity $(52.7 \%)$ was found between Finland strain KY548519 and Uşak05 and Hah-3 isolates, the highest similarity (98.9\%) was found between Canada isolate M58757, Hatay07, Ankara10 and Hah-2.

The results of this study can help in developing specific sanitation methods in protection from IPNV and epidemiological connections. The presence of IPNV carriers in brood stock fish is an alarming situation especially for spawners. Through larvae and eggs taken from these spawners, the infection is transferred to other farms. In order to protect from vertical infection of IPNV, the source of the disease should be eliminated by routine checks, determination of IPNV carrier spawners and taking out the carrier brood stock from aquaculture units. Producers should buy eggs and fries after having IPNV control tests and certifications should be made compulsory especially for hatcheries. While fishery industry is developing fast in many countries of the world, failure in fighting this infection is resulting with economic loss. Due to the presence of "persistent IPNV strains" in hatcheries, the elimination of this disease is difficult. Developing effective vaccines and presenting these to the market will contribute to fighting the disease.

\section{Acknowledgments}

This article was produced from the first author's $\mathrm{PhD}$ thesis entitled "Molecular Characterization and Pathogenicity Tests of Native Infectious Pancreatic Necrosis Virus Isolates". This study was funded by directorate general of agricultural researches and policies (TAGEM) with a Project number of TAGEM/HSGYAD/ 17/A05/P04/92 and by Ondokuz May1s University Scientific Research Projects Commission Directorate with a Project number of PYO.VET.1904.17.012. 


\section{Conflict of Interest}

The authors declared that there is no conflict of interest.

\section{References}

1. Ahmadivand S, Soltani M, Behdani M, et al (2018): VP2 (PTA motif) encoding DNA vaccine confers protection against lethal challenge with infectious pancreatic necrosis virus (IPNV) in trout. Mol Immunol, 94, 61-67.

2. Albayrak H (2017): The determination of molecular characterization and genetic analysis of IPNV field strains isolated from Turkey: The classic and recombinant vaccine trials and the development of diagnostic kit. Ondokuz May1s University Faculty of Veterinary Medicine, Samsun, Project of TUBITAK, Project Number: 213O156, 1-114.

3. Blake S, Ma JY, Caporale DA, et al (2001): Phylogenetic relationships of aquatic birnaviruses based on deduced amino acid sequences of genome segment A cDNA. Dis Aquat Org, 45, 89-102.

4. Candan A (2002): First report on the diagnosis of infectious pancreatic necrosis (IPN) based on reverse transcription polymerase chain reaction (RT-PCR) in Turkey. Bull Eur Ass Fish Pathol, 22, 45-48.

5. Cuesta A, Chaves-Pozo E, De Las Heras AI, et al (2010): An active DNA vaccine against infectious pancreatic necrosis virus (IPNV) with a different mode of action than fish rhabdovirus DNA vaccines. Vaccine, 28, 3291-3300.

6. Dadar M, Peyghan R, Rajabi-Memari H, et al (2014): Infectious pancreatic necrosis virus (IPNV) based on deduced amina acid sequences of genom segment $A$ and $B$ cDNA. Iran J Fish Sci, 13, 560-575.

7. Davies KR, McColl KA, Wang LF, et al (2010): Molecular characterisation of Australasian isolates of aquatic birnaviruses. Dis Aquat Org, 93, 1- 15.

8. Dobos P (1976): Size and structure of the genome of infectious pancreatic necrosis virus. Nucleic Acids Res, $\mathbf{3}$, 1903-1924.

9. Dobos P (1995): The molecular biology of infectious pancreatic necrosis virus (IPNV). Ann Rev Fish Dis, 5, 2554.

10. Duncan R, Mason CL, Nagy E, et al (1991): Sequence analysis of infectious pancreatic necrosis virus genome segment $B$ and its encoded VPI protein: a putative RNAdependent RNA polymerase lacking the Gly-Asp-Asp motif. Virology, 181, 541-552.

11. Estévez RA, Mostazo MGC, Rodriguez E, et al (2018): Inducers of salmon innate immunity: An in vitro and in vivo approach. Fish Shellfish Immunol, 72, 247-258.

12. Heppell J, Tarrab E, Berthiaume L, et al (1995): Characterization of the small open reading frame on genome segment $A$ of infectious pancreatic necrosis virus. $\mathrm{J}$ Gen Virol, 76, 2091-2096.

13. Ji F, Zhao JZ, Liu M, et al (2017): Complete genomic sequence of an infectious pancreatic necrosisvirus isolated from rainbow trout (Oncorhynchus mykiss) in China. Virus Genes, 53, 215-225.
14. Julin K, Mennen S, Sommer A-I (2013): Study of virulence in field isolates of infectious pancreatic necrosis virus obtained from the northern part of Norway. J Fish Dis, 36, 89-102.

15. Manríquez RA, Vera T, Villalba VM, et al (2017): Molecular characterization of infectious pancreatic necrosis virus strains isolated from the three types of salmonids farmed in Chile. Virol J, 14, 1-16.

16. Mutoloki S, Evensen Ø (2011): Sequence similarities of the capsid gene of Chilean and European isolates of infectious pancreatic necrosis virus point towards a common origin. J Gen Virol, 92, 1721-1726.

17. Nishizawa T, Kinoshita S, Yoshimizu M (2005): An approach for genogrouping of Japanese isolates of aquabirnaviruses in a new genogroup VII based on the VP2/NS junction region. J Gen Virol, 86, 1973-1978.

18. Ørpetveit I. Mikalsen AB, Sindre H, et al (2010): Detection of infectious pancreatic necrosis virus in subclinically infected atlantic salmon by virus isolation in cell culture or real-time reverse transcription polymerase chain reaction: influence of sample preservation and storage. J Vet Diagn Invest, 22, 886-895.

19. Salgado-Miranda C, Rojas-Anaya E, Garcia-Espinosa G, et al (2014): Molecular characterization of the VP2 gene of infectious pancreatic necrosis virus (IPNV) isolates from Mexico. J Aquat Anim Health, 26, 43-51.

20. Santi N, Vakharia VN, Evensen $\varnothing$ (2004): Identification of putative motifs involved in the virulence of infectious pancreatic necrosis virus. Virology, 322, 31-40.

21. Santi N, Sandtro A, Sindre H, et al (2005): Infectious pancreatic necrosis virus induces apoptosis in vitro and in vivo independent of VP5 expression. Virology, 342, 13-25.

22. Santi N, Song H, Vakharia VN, et al (2005): Infectious pancreatic necrosis virus VP5 is dispensable for virulence and persistence. J Virol, 79, 9206-9216.

23. Shivappa RB, Song H, Yao K, et al (2004): Molecular characterization of Sp serotype strains of infectious pancreatic necrosis virus exhibiting differences in virulence. Dis Aquat Org, 61, 23-32.

24. Skjesol A, Skjæveland I, EInæs M, et al (2011): IPNV with high and low virulence: host immune responses and viral mutations during infection. Virol J, 8, 396-410.

25. Song H, Santi N, Evensen Ø, et al (2005): Molecular determinants of infectious pancreatic necrosis virus virulence and cell culture adaptation. J Virol 2005, 79, 10289-10299.

26. Weber S, Fichtner D, Mettenleiter TC, et al (2001): Expression of VP5 of infectious pancreatic necrosis virus strain VR299 is initiated at the second in-frame start codon. J Gen Virol, 82, 805-812.

27. Wen CM (2017): Complete genome sequence and phylogenetic analyses of an aquabirnavirus isolated from a diseased marbled eel culture in Taiwan. Arch Virol, 162, 2467-2471.

28. Zhu L, Wang X, Wang K, et al (2017): Outbreak of infectious pancreatic necrosis virus (IPNV) in farmed rainbow trout in China. Acta Trop, 170, 63-69. 